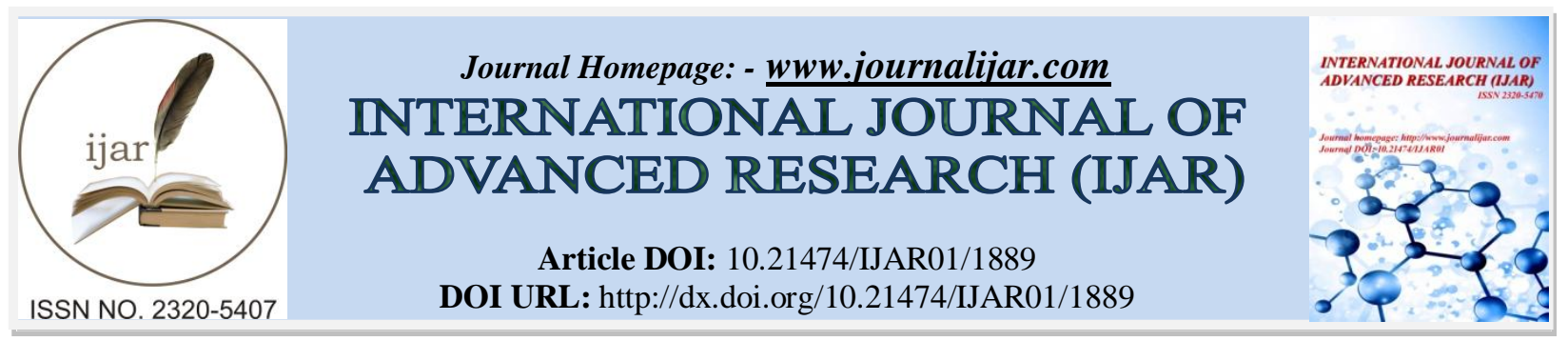

RESEARCH ARTICLE

\title{
A STUDY OF IMMUNE RESPONSE AND SIDE EFFECTS OF SECOND LINE ANTIRETROVIRAL THERAPY IN HIV/ AIDS PATIENTS.
}

Arvind Chahal, PS Ghalaut, Sudhir Kumar Atri, Naresh Gaur, Isha Pahuja and Akhilesh Singhal.

\section{Manuscript Info}

Manuscript History

Received: 13 August 2016

Final Accepted: 19 September 2016

Published: October 2016

Key words:-

AIDS, Second Line ART, HIV RNA, CD4.

\section{Abstract}

Only recently second line ART treatment has become available in developing countries. The data on the effects of the second line ART in these settings are limited. Our aim was to analyze treatment outcomes of patients receiving second line antiretroviral therapy (ART) through the National AIDS Control Programme of India. This study was carried out in 28 patients more than 18 years of age; on second line ART as per NACO guidelines at Pt B D Sharma PGIMS Rohtak, a tertiary care hospital in Haryana which is a low prevalence state. The patients were followed up for six months. The study cohort was having mean age of $32 \pm 10.77$ years. Patients were prescribed Second line ART regimen according to NACO guidelines i.e. fixed dose combination of Tenofovir $300 \mathrm{mg}+$ lamivudine $300 \mathrm{mg}$ once daily in tablet form; tablet Atazanavir 300mg and tablet Ritonavir $100 \mathrm{mg}$; each tablet to be taken simultaneously daily. At the end of study, mean body weight increased from $52.11 \pm 10.46 \mathrm{Kg}$ to $55.29 \pm$ $10.70 \mathrm{Kg}$; Mean BMI increased from $19.05 \pm 3.11 \mathrm{Kg} / \mathrm{m} 2$ to $20.24 \pm$ $3.23 \mathrm{Kg} / \mathrm{m} 2$ and mean hemoglobin increased from $11.53 \pm 2.33 \mathrm{gm} \%$ to $11.71 \pm 3.62 \mathrm{gm} \%$. After six months on second line ART the mean CD4 count of the cohort has increased from 80 to 214 cells per cumm and mean HIV RNA load decreased from 472189.29 copies per ml to 426.39 copies per $\mathrm{ml}$. The rise in weight , BMI, CD4 count and fall in HIV RNA was statistically significant $(\mathrm{P}<0.05)$.

Copy Right, IJAR, 2016,. All rights reserved.

\section{Introduction:-}

Nearly 30 years since the start of HIV epidemic; it remains a major public health problem. In last two decades there have been major advances in treatment of HIV infected patients with advent of Highly Active Anti Retroviral Therapy (HAART) ${ }^{1}$. The HIV virus is continuously evolving and over time the response to HAART has changed. This has led to firstline ART failure necessitating switch to Second line. The Current NACO treatment guidelines ${ }^{2}$ recommend use of Ritonavir-boosted protease inhibitors supported by two agents from the NRTI class; of which at least one should be new. The second line ART regimens comprised of tenofovir (TDF), lamivudine(3TC), and boosted Atazanavir/ritonavir (ATV/r). The patients qualify for second line ART if they demonstrate CD4 decline to pre-ART values, CD4 drop to less than 50\% of peak on-treatment value, failure to achieve CD4 greater than 100 $\mathrm{c} / \mathrm{mm}$ (immunologic failure), or develop a new WHO stage III/IV AIDS-defining illness (clinical failure), or those with HIV RNA $5000 \mathrm{c} / \mathrm{ml}$ or greater (virological failure). ${ }^{3}$ 


\section{Materials and Methods:-}

The present prospective study was carried out in the Department of Medicine/ART Centre, Pt. B.D. Sharma, Post Graduate Institute of Medical Sciences Rohtak. The study included HIV positive patients, age 18 years or more, in whom first line therapy has failed and who were on second line antiretroviral therapy as per NACO guidelines ${ }^{2}$ either admitted in ward or attending outpatient department. The written informed consent was taken. All the patients were clinically assessed at the start of study then every month till six months. Patients were prescribed fixed dose combination of Tenofovir $300 \mathrm{mg}+$ lamivudine $300 \mathrm{mg}$ once daily in tablet form; tablet Atazanavir $300 \mathrm{mg}$ and tablet Ritonavir100mg; each tablet to be taken simultaneously daily. Patients were followed up monthly for six months and during this period, assessed for immune response to second line ART, changes in weight, BMI, Hemoglobin, Blood Sugar, liver function test, renal function test, electrocardiogram, Lipid Profile and any possible side effects.

\section{Results \& Discussion:-}

At the start of study; the chief presenting complaints were loss of weight and appetite in 15 patients, generalised weakness in 9, fever in 7, loose stool in 5, oral ulceration in 5, cough in 4, dysphagia in one, and altered sensorium in one patient. The most common clinical finding observed was icterus in 12 patients, Pallor was present in 4 patients, Lymph nodes were present in one patients. At the start of study patient had opportunistic infections most common being oral candidiasis in 2 patients, 2 patients having fever and diarrhea of one month duration , tuberculosis in 3 patients ( 2 patients of pulmonary and 1 patients of CNS tuberculosis). One patient was found to be HbsAg positive. Treatment for opportunistic infections was given. 3 patients were given ATT, and 7 patients were given tablet fluconazole for oral candidiasis. Patients were also given prophylaxis for opportunistic infections according to NACO guidelines. PCP prophylaxis was prescribed to 12 patients and MAC Prophylaxis was prescribed to 6 patients.

\section{Baseline parameters:-}

Out of twenty eight patients; 22 were male and 6 were female. Most common age group was 26-35 years. There were 26 married patients, amongst them partners of 20 patients were also reactive. In our study mean age was $32 \pm$ 10.77 years which was comparable with study conducted by Kumarsamy et $\mathrm{al}^{4}$ (mean age 35 years). Mean was higher in studies conducted by Patel D et $\mathrm{al}^{6}$ (39.6 years), Jansen et $\mathrm{al}^{7}$ (43 years) and Betty J Dong et $\mathrm{al}^{5}$ (47years). The reason for higher age in Betty $\mathrm{J}^{\text {Dong }}{ }^{5}$ and Jansen et $\mathrm{al}^{7}$ study cohorts may be as they were conducted in developed countries and while studies of Patel $\mathrm{D}^{6}$, Kumarsamy et $\mathrm{al}^{4}$ were conducted in countries having limited resources implying disease being diagnosed at advance stage with frequent first line failure and necessitating a early switch to second line ART. (Table I)

Table No. I:- Baseline characteristics in various studies.

\begin{tabular}{|c|c|c|c|c|c|}
\hline & Present study & Patel et $\mathrm{al}^{6}$ & 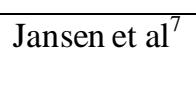 & Betty J Dong et $\mathrm{al}^{5}$ & $\begin{array}{l}\text { Kumarsamy et } \\
\mathrm{al}^{4}\end{array}$ \\
\hline $\begin{array}{l}\text { Number } \\
\text { patients }\end{array}$ & 28 & 126 & 1294 & 131 & 91 \\
\hline $\begin{array}{l}\text { Mean/median age } \\
\text { (years ) }\end{array}$ & $32 \pm 10.77$ & $39.6 \pm 9.4$ & 43 & $47 \pm 9.6$ & 35 \\
\hline Sexratio $(\mathrm{M}: \mathrm{F})$ & $3.66: 1$ & $2.7: 1$ & $2.9: 1$ & $64.5: 1$ & $3: 1$ \\
\hline $\begin{array}{l}\text { Weight }(\mathrm{kg}) \\
\text { Mean/median }\end{array}$ & $52.7 \pm 10.46$ & $47.8 \pm 0.8$ & - & - & - \\
\hline $\begin{array}{l}\text { BMI }\left(\mathrm{kg} / \mathrm{m}^{2}\right) \\
\text { Mean } / \text { median }\end{array}$ & $19.05 \pm 3.11$ & $19.8(16.5-22.5)$ & - & - & 19.8 \\
\hline $\begin{array}{l}\text { Base line CD4 } \\
\text { count } \\
\text { (cells/cumm) } \\
\text { Mean/median }\end{array}$ & $80.29 \pm 51.79$ & $\begin{array}{l}123.7 \\
\pm 10.1\end{array}$ & 368 & 475 & 119 \\
\hline
\end{tabular}

\section{Efficacy Predictors:-}

In our study mean weight of subjects increased from $52.11 \pm 10.46 \mathrm{Kg}$ to $55.29 \pm 10.70 \mathrm{Kg}$ over a period of six months. The increase in mean weight of cohort was $3.1 \mathrm{~kg}$ and it was statistically significant $(\mathrm{P}<0.0001)$. In study by Patel D et $\mathrm{al}^{6}$ mean baseline weight of patients was $47.8 \pm 0.8 \mathrm{~kg}$ mean weight gain was $3 \mathrm{~kg}$ which was almost similar to that of our study. The mean BMI also increased during follow up period. from $19.05 \pm 3.11 \mathrm{Kg} / \mathrm{m} 2$ to 
$20.24 \pm 3.23 \mathrm{Kg} / \mathrm{m} 2$.The rise was statistically significant $(\mathrm{P}<0.05)$. After six months, Mean haemoglobin increased from $11.532 \pm 2.33 \mathrm{gm} \%$ to $11.711 \pm 3.62 \mathrm{gm} \%$. The rise in haemoglobin was not statistically significant.

The mean CD4 count increased in all subjects from 81 cells $/ \mathrm{mm}$ at baseline to 214 cells per cubic $\mathrm{mm}$ at six month. The increase in CD4 count was $167 \%$ as compared to baseline CD4 count and it was statistically significant (P < 0.00001). The rise in CD4 count in our study was higher which may be because of baseline CD4 count was low i.e. 81 as compared to study conducted by Jansen et $\mathrm{al}^{7}$ and Betty J Dong et $\mathrm{al}^{5}$ in which baseline CD4 count was 368 and 475 respectively. (TABLE II)

Table No. II:- Comparative rise in Mean/Median CD4 counts.

\begin{tabular}{|l|l|l|l|l|l|}
\hline & Present study & patel $^{6}$ et al & $\begin{array}{l}\text { Kumarsamy } \\
\text { al }\end{array}$ & Jansen et al & $\begin{array}{l}\text { Betty J } \\
\text { Dong et al }^{5}\end{array}$ \\
\hline Number of patients & 28 & 126 & 91 & 1294 & 131 \\
\hline $\begin{array}{l}\text { Mean /median CD4 } \\
\text { cell count (cells/cumm) }\end{array}$ & $80.29 \pm 51.7$ & $123.7 \pm 10.1$ & 119 & 368 & 475 \\
\hline $\begin{array}{l}\text { Total Increase in CD4 } \\
\text { cell count (cells/cumm) }\end{array}$ & 134 & 155 & 203 & $\begin{array}{l}48 \text { cells/ul/ } \\
\text { year }\end{array}$ & 26 \\
\hline
\end{tabular}

In present study mean HIV RNA load at base line was 472189 copies per ml which after six months of second line ART reduced to mean level of 426 i.e. $99.90 \%$ suppression of HIV RNA . In study conducted by Patel et $\mathrm{al}^{6}$ mean HIV RNA load at base line was 216810 which after six months reduced to mean level of 1433 i.e. $99.33 \%$ suppression of HIV RNA. The decrease in HIV RNA load was similar to our study and it was statistically significant ( $\mathrm{P}$ value $<0.05$ ).

\section{Adverse events:-}

Out of total twenty eight patients followed up for six months, $78 \%(22 / 28)$ patients reported at least one type of toxicity. The most common adverse events within six months after switch to second line drugs were indirect hyperbilirubinemia(65\%), hepatotoxicity $(42.85 \%)$, dyslipidemia $(28.75 \%)$, anemia and diarrhea $(14.28 \%)$, renal toxicity(10\%), oral ulceration nausea and vomiting in $7.14 \%$. The relative high incidence of hyperbilirubinemia in our study may be because atazanavir in second line drugs.

Dyslipidemia was observed in $28.75 \%$ patients which was lower than other studies. The less incidence of dyslipidemia may be because atazanavir is more lipid friendly than lopinavir. Lopinavir was used in cohorts of Patel $\mathrm{D}$ et $\mathrm{al}^{6}$. Anemia was observed in $14.28 \%$ cases in our study group. The more incidence of anemia may be due to more female in our study group in reproductive age and also due to wide spread prevalence of iron deficiency in our state. Nausea, vomiting and diarrhoea was observed more in initial months of therapy in $28.42 \%$ patients in our study. Renal toxicity was observed in $10 \%$ cases that was quite higher than study conducted by Jansen et $\mathrm{al}^{7}(0.60 \%$ cases). Hyperpigmentation was reported in $3.57 \%$ patient which includes pigmentation of skin over forehead in our study. Peripheral neuropathy was reported in $3.5 \%$, oral ulcers were observed during first month in $7.14 \%$ patients and they resolved spontaneously. (Table III)

Table No. III:- Comparative incidences of adverse events.

\begin{tabular}{|c|c|c|c|c|}
\hline Adverse events & Present study & patel et al ${ }^{65}$ & Kumarsamy et $\mathrm{al}^{63}$ & Jansen et $\mathrm{al}^{6 \mathrm{6}}$ \\
\hline Hepatotoxicity & $42.85 \%$ & - & - & 7.5 \\
\hline Dyslipidemia & $28.75 \%$ & $45.23 \%$ & & $20 \%$ \\
\hline Anemia & $14.28 \%$ & $7.14 \%$ & & \\
\hline Diarrhoea & $14.28 \%$ & - & $6.1 \%$ & $4 \%$ \\
\hline Urine albumin & $10 \%$ & - & - & $00.60 \%$ \\
\hline Nausea /vomiting & $7.14 \%$ & - & $14.8 \%$ & $1 \%$ \\
\hline Oral ulcers & $7.14 \%$ & - & - & - \\
\hline Hyperpigmenation & $3.57 \%$ & - & 14.4 & - \\
\hline Peripheral neuropathy & $3.5 \%$ & - & $7 \%$ & - \\
\hline
\end{tabular}

\section{Conclusion:-}

Our study demonstrates that there was a rise of $167 \%$ in CD4 count in all cases and suppression of HIV RNA Load to the extent of $99.90 \%$ in $75 \%$ of cases; after six months of second line ART consisting of Tenofovir300 mg, lamivudine300mg; tablet Atazanavir300mg and tablet Ritonavir100mg in HIV positive patients who are first line 
failure as defined by NACO guidelines. Second line ART therapy after six months of treatment also leads to significant increase in mean weight and mean BMI. 78\% of cases reported side effects of second line ART. Hyperbilirubinemia was most common which may be due to tablet Atazanavir. The study showed that second line ART was efficacious and well tolerated.

\section{References:-}

1. Antiretroviral therapy guidelines for HIV-Infected adults and adolescents;May 2013:7-58

2. National AIDS Control Organization of India. HIV data. Available from http:// www.nacoonline.org/Quick_links/HIV_Data (accessed on 2 December 2014

3. Ministry of Health and Family Welfare, Government of India; 2011. NACO. National guidelines on second line ART.5-25

4. Kumarasamy N, Venkatesh KK, Devaleenal B et al. Safety, Tolerability, and Efficacy of Second-Line Generic Protease Inhibitor Containing HAART after First-Line Failure among South Indian HIV-Infected Patients. J Int Assoc Physicians AIDS Care (Chic). 2011 Mar-Apr;10(2):71-5.

5. Dong BJ, Ward DJ, Chamberlain LA et al. Safety and Effectiveness of Tenofovir/Emtricitabine or Lamivudine Plus Ritonavir Boosted Atazanavir in Treatment Experienced HIV Infected Adults at Two Urban Private Medical Practices. J Antivir Antiretrovir 2012.

6. Dishank Patel, Mira Desai, A. N. Shah et al. Early outcome of second line antiretroviral therapy in treatmentexperienced human immunodeficiency virus positive patients. Perspect Clin Res. 2013 Oct-Dec; 4(4): 215-20.

7. Klaus Jansen, Anders So"nnerborg, Norbert Brockmeyer et al. Long-Term efficacy and safety of Atazanavir/Ritonavir treatment in a real-life cohort of treatment-experienced patients with HIV Type 1 Infection. Aids Research and Human Retroviruses Volume 29, Number 3, 2013. 